日本臨床麻酔学会第29回大会シンポジウム

神経ブロック 超音波ガイドの現状と今後の領域

腰部，仙骨領域に対する超音波ガイド下神経ブロックの現状と今後 一腰神経叢ブロックおよび傍仙骨ブロックの, 神経刺激単独法と超音波ガイド・神経刺激併用法の比較—

$\begin{aligned} \text { 原戸美佐子* } & \text { 伊藤 } \\ \text { 小洋* 明石 学* } & \text { 徹* 藤原祥裕* }\end{aligned}$

\begin{abstract}
[要旨] 近年多くの末梢神経ブロックが超音波ガイド下で行われるようになった. し かしながら深部の末梢神経ブロックは神経の描出が難しく, 従来どおり神経刺激単独 法で行われることが多かった. 超音波画像により神経そのものを描出できなくとも, 骨組織や筋組織といつた超音波解剖ランドマークを描出し，それらを指標に神経刺激 を併用してリアルタイムに穿刺を行うのが超音波ガイド・神経刺激併用法である. 本 稿では腰神経叢ブロック，傍仙骨ブロックにおける超音波ガイド・神経刺激併用ブロ ック法の手技の詳細について説明した. また，人工膝関節置換手術患者を対象に腰神 経叢ブロックおよび傍仙骨ブロックを神経刺激単独法および超音波ガイド・神経刺激 併用法で行い比較検討した. 手技に要した時間, 術中術後の鎮痛薬使用量, 術中血行 動態，術後の鎮痛効果は両群間で有意差を認めなかった．ブロック針穿刺時，神経刺 激単独法群で 1 例, 血液逆流を認めた.

キーワード : 腰神経叢ブロック, 傍仙骨ブロック, 超音波ガイド・神経刺激併用, 人 工䐈関節置換手術, 術後鎮痛
\end{abstract}

(日臨麻会誌Vol.30 No.7, $952 ＼mathrm{~ 958, ~ 2010) ~}$

はじめに

人工膝関節置換術 $(T K A)$ は疼痛が強いことが知 られている。術中疼痛は血圧や脈拍の上昇といった 自律神経反射，カテコラミン分泌増加をもたらし， 術後疼痛は患者のQOLの低下, 離床の遅れ, 在院 期間の延長などをもたらす。局所鎮痛による術後疼 痛管理は合併症を減少させ，予後を改善することが 知られている ${ }^{1)}$. TKA に対する術中術後鎮痛方法

*愛知医科大学医学部麻酔科学講座
として，わが国では持続硬膜外鎮痛が多用されてき たが，周術期の静脈血栓塞栓症予防目的で抗凝固療 法が積極的に行われるようになり，持続硬膜外鎮痛 のためのカテーテル留置は相対的禁忌となった ${ }^{2)}$. われわれの施設ではTKAに対し，全身麻酔に末梢 神経ブロックを併用する麻酔管理をしている。 TKAの下肢神経ブロックは下肢全域の神経遮断が 必要となるため, 腰神経叢ブロックと傍仙骨ブロッ クを選択している。両神経は深部にあるために超音 愛知医科大学医学部麻酔科学講座 


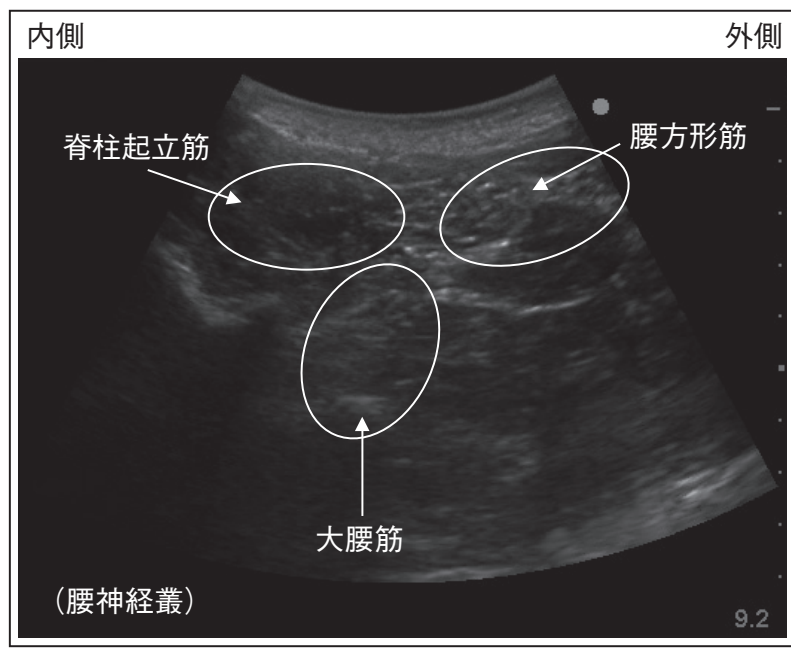

図 1 大腰筋近傍の超音波画像

波画像により神経を描出することが困難である。そ のため，これまで神経刺激単独法を用いて神経ブロ ックを行ってきた。われわれは標的となる神経その ものでなく，深部でも描出しやすい骨や筋組織の超 音波解剖画像と神経刺激ガイドを併用してブロック 針先端を適切な位置へ誘導し, 神経ブロックを施行 する，超音波ガイド・神経刺激併用末梢神経ブロッ クを試みた。本稿では超音波ガイド・神経刺激併用 による腰神経叢ブロックと傍仙骨ブロックの方法 の詳細を紹介し, 神経刺激単独法との比較検討を 行つた.

\section{TKAに必要な末梢神経ブロック}

TKA では腰神経叢のうち大腿神経, 外側大腿皮 神経，閉鎖神経，大腿神経末枝としての伏在神経， 仙骨神経叢は坐骨神経(脛骨神経・総腓骨神経)，後 大腿皮神経の遮断が必要となる。それぞれの神経に 対して遠位末梢で神経ブロックを施行すると，ブロ ック箇所が多数に及び，使用する局所麻酔薬量が多 量となる。近位で神経ブロックを行うことにより， 最小限の神経ブロック部位と局所麻酔薬の量で最も 広範囲の神経遮断が期待できる。われわれは腰神経 盖ブロックと傍仙骨ブロックを施行している.

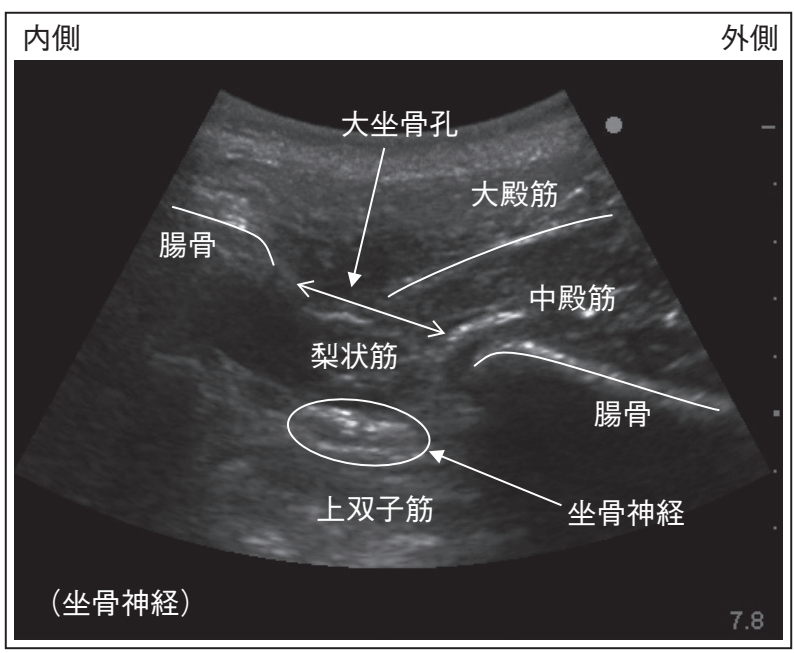

図2 大坐骨孔近傍の超音波画像

\section{II ブロックの手技}

\section{1. 腰神経叢ブロック}

1) 解剖

腰神経叢はL1-L4の脊髄神経前枝で構成される. 腰神経は大腰筋背部 $1 / 3$ 中を走行する。腰椎椎体の 外側に大腰筋が存在する。大腰筋はL1-L5の横突 起，Th12-L5の椎体，および各腰椎の椎間円板を 起始とし，小転子に付着して終わる。腰神経叢ブロ ックはL3-4あるいはL4-5の横突起間から大腰筋に 向かって針を刺入する。大腰筋は後腹膜腔に隣接し ており，腎臓，腎動静脈，腹部大動脈，下大静脈な ぞが近傍に存在する ${ }^{3)}$.

2)神経刺激単独法

L3，L4，L5 の棘突起を結ぶ正中線を描く。正中 線から腸骨稜に向かって垂直線を描き，正中線から $40 \mathrm{~mm}$ の地点を刺入部位とする。これは L4 椎体の 外側に位置する。刺入部位に局所麻酔を施行したあ と, 神経刺激ブロック針 $\left(\right.$ Stimuplex ${ }^{\circledR}$ needle $100 \mathrm{~mm}$, B. Braun) を刺入する。振幅 $1.5 \mathrm{~mA}$, 周波数 $2 \mathrm{~Hz}$, 刺激時間 $0.1 \mathrm{mS}$ で神経刺激しながら針を垂直に進め ていく，右手に針を持ち，左手で刺入部位周辺の皮 膚を固定しながら針を進める。まず，脊柱起立筋の 収縮が左手に感じられる。さらに，針を横突起まで 
表 1 患者背景

\begin{tabular}{ccc}
\hline & 神経刺激単独 & $\begin{array}{c}\text { 超音波ガイド・ } \\
\text { 神経刺激併用 }\end{array}$ \\
\hline 年齢(歳) & $74 \pm 8.1$ & $80 \pm 4.6$ \\
性別 $(\mathrm{M} / \mathrm{F})$ & $4 / 2$ & $4 / 2$ \\
身長 $(\mathrm{cm})$ & $153 \pm 6.9$ & $149 \pm 6.1$ \\
体重 $(\mathrm{kg})$ & $57 \pm 7.6$ & $56 \pm 3.5$ \\
ASA $(1 / 2)$ & $0 / 6$ & $0 / 6$ \\
手術時間 $(\mathrm{min})$ & $135 \pm 23$ & $144 \pm 46$ \\
麻酔時間 $(\mathrm{min})$ & $225 \pm 16$ & $240 \pm 56$ \\
駆血時間 $(\mathrm{min})$ & $137 \pm 24$ & $124 \pm 27$ \\
出血量 $(\mathrm{g})$ & $49 \pm 38$ & $133 \pm 170$ \\
尿量 $(\mathrm{ml})$ & $227 \pm 110$ & $177 \pm 141$ \\
輸液量 $(\mathrm{ml})$ & $1308 \pm 102$ & $1570 \pm 271$ \\
\hline
\end{tabular}

mean $\pm \mathrm{SD}$ n.s.

進める，次に，頭側あるいは尾側に向け針を刺入し 直す。皮膚から横突起までの距離 $+2 \mathrm{~cm}$ を超えて 刺入はしない，横突起から腰神経叢までの距離は $1.5 \mathrm{~cm}$ から $2 \mathrm{~cm}$ である ${ }^{4)}$. それを超えて刺入すると， 腹腔内穿刺の危険性が高くなる。大腿四頭筋の収縮 を認めたら神経刺激振幅を下げ，0.5mA で収縮がみ られる位置にブロック針を微調整する。さらに刺激 振幅を $0.2 \mathrm{~mA}$ まで下げて収縮が消失するのを確認 する。これは針が神経内に刺入されていないことを

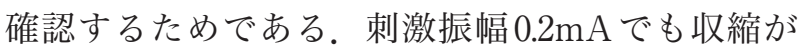
みられれば，収縮が消失するまで針の位置を調整す

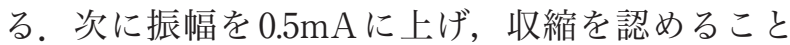
を確認し, 血液逆流テストを施行したのち, 局所麻 酔薬を注入する。

3)超音波ガイド・神経刺激併用法

コンベクスプローブを使用する。䊂突起の外側に プローブを当てて (矢状断)，仙骨，L5，L4，L3の 棘突起を確認する。プローブを外側に移動して, L3 横突起が画面の正中になるようにプローブの位 置を調整する。L3横突起を超音波画像でとらえた まま，プローブを反時計回りに $90^{\circ}$ 回転させる，次 にプローブを外側に移動し, 傾けて, L3 横突起の 音響陰影を確認する。プローブを横突起による音響
表2 使用薬片量

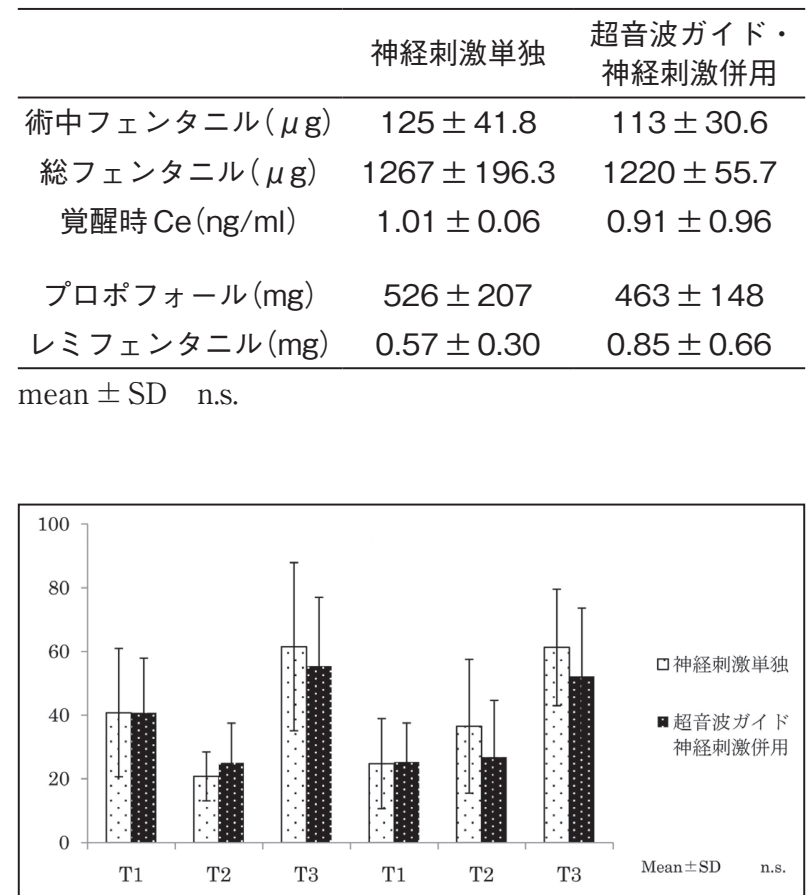

图3 ブロックに要した時間 (秒)

$\mathrm{T} 1$ : 穿刺から $1.5 \mathrm{~mA}$ で筋収縮を認めるまでの時間

$\mathrm{T} 2$ : 刺激を $1.5 \mathrm{~mA}$ から $0.6 \mathrm{~mA}$ まで落とし筋収縮が得 られ，かつ $0.2 \mathrm{~mA}$ まで落として筋収縮が消失す るのを確認するまでの時間

$\mathrm{T} 3: \mathrm{T} 1+\mathrm{T} 2$ (穿刺から局所麻酔薬注入まで)

陰影が消失する部位まで頭側あるいは尾側に移動さ せると, 超音波画像に大腰筋が描出される(図1). ここで，大腰筋に向けてブロック針を刺入する。次 に，神経刺激器によるガイドを神経刺激単独法と同 様に行い局所麻酔薬を注入する。

\section{2. 傍仙骨ブロック}

1) 解剖

仙骨神経叢は L4-S3の脊髄神経前枝で構成され る。仙骨神経叢は骨盤内から大坐骨孔を通り骨盤外 へと出て坐骨神経となる。また，仙骨神経叢は大坐 骨孔から出たあとすぐに，後大腿皮枝を分布し，尾 側へと走行し，膝窩部の頭側で脛骨神経と総腓骨神 経に分かれる。傍仙骨ブロックは大坐骨孔から坐骨 神経が出てくる部位に局所麻酔薬を注入し, 神経ブ ロックを行うので後大腿皮枝も含めて坐骨神経叢の 


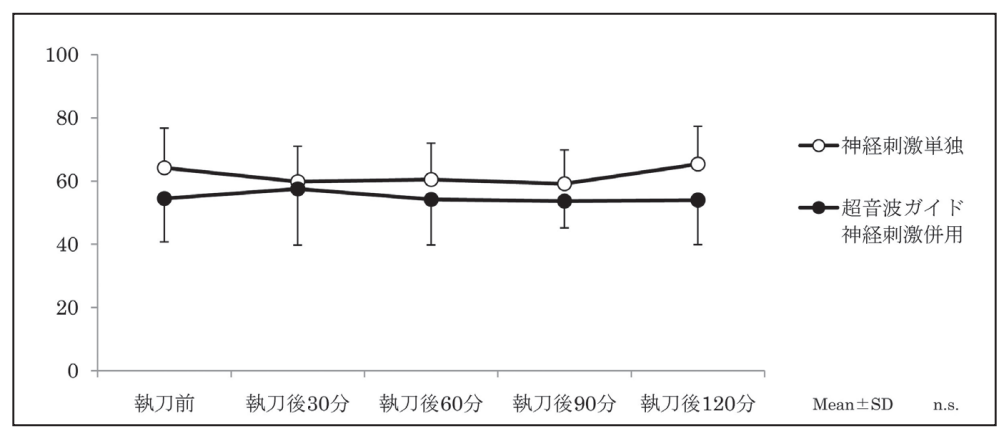

図4 心拍数 (bpm)

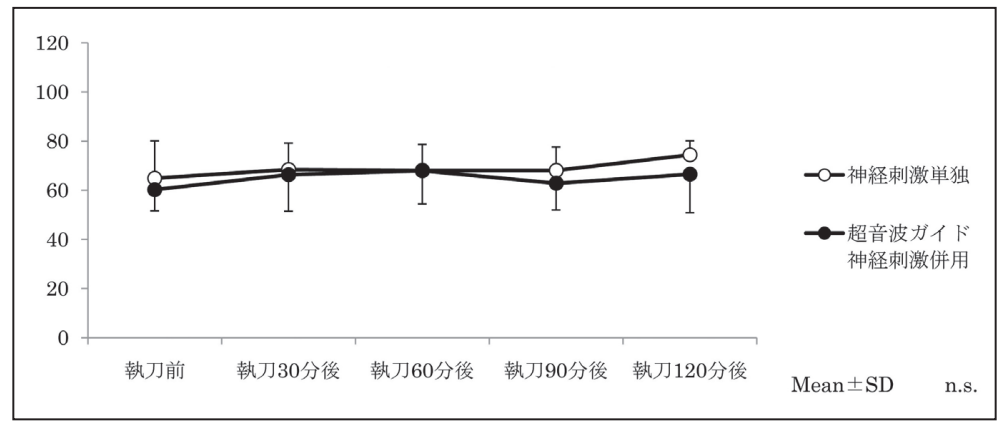

図 5 平均血压 $(\mathrm{mmHg})$

すべての枝がブロックされる5 .

2)神経刺激単独法

後上腸骨棘と坐骨結節の体表ランドマークを結ぶ 直線を描き, 後上腸骨棘から $60 \mathrm{~mm}$ の地点を刺入部 位とする。腰神経叢ブロックと同様に神経刺激ガイ ドでブロック針を誘導する、針を進めていくと，最 初に中殿神経の神経刺激により大殿筋が収縮する。 さらに針を進め足関節の底屈あるいは背屈を認めた ら血液吸引テストののち薬液を注入する。神経刺激 器の設定は腰神経叢ブロックと同様にする。大殿筋 の収縮による下肢の摇れを，坐骨神経の刺激による ものと誤らないように注意が必要である。大腿二頭 筋，半腱様筋，半膜様筋の収縮を認めるときは針の 刺入方向を内側に変える。坐骨に当たるようであれ ば，尾側へと針の刺入方向を変える。刺入部位から $6.0 \mathrm{~cm} \sim 7.0 \mathrm{~cm}$ ，坐骨神経より $0.8 \mathrm{~cm} \sim 2.8 \mathrm{~cm}$ の位置 に小腸，卵巣，血管等の骨盤内組織が存在するため 注意が必要である ${ }^{6)}$.
3)超音波ガイド・神経刺激併用法

コンベクスプローブを使用する。神経刺激単独法 と同様に体表ランドマークを作図する。プローブを 後上腸骨棘の上に直線と直交するように置き腸骨を 描出する。腸骨は高エコー像を示す構造物として容 易に認識できる。プローブを坐骨に向かって移動さ せると，骨の切れ目に大坐骨孔が視認でき，大坐骨 孔の中に坐骨神経が確認できる(図2)。外側あるい は内側より平行法にてブロック針を刺入する。神経 刺激によるガイドは神経刺激単独法と同様に行う。

\section{III 神経刺激単独法と 超音波ガイド・神経刺激併用法の比較}

$<$ 対象 $>$

TKAを予定された 12 名の成人患者を無作為に神 経刺激単独群(6名), 超音波ガイド・神経刺激併用 群(6名)に分け, 腰神経垪ブロックと傍仙骨ブロッ クを行った。 


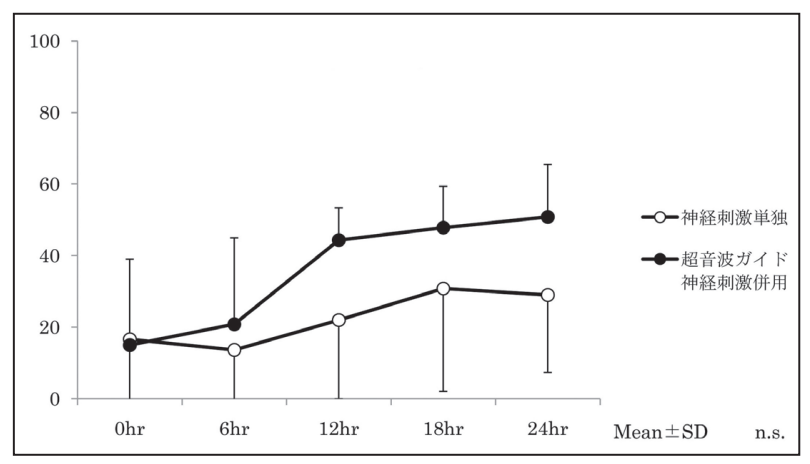

図6 安静時VAS スコア

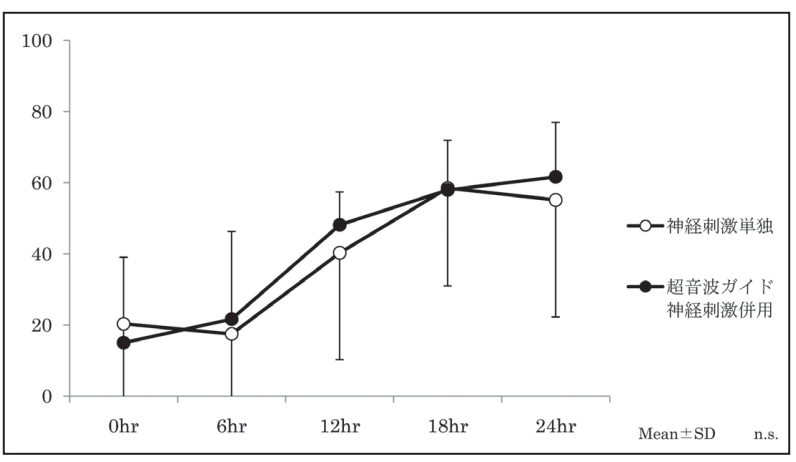

図 7 体動時 VAS スコア

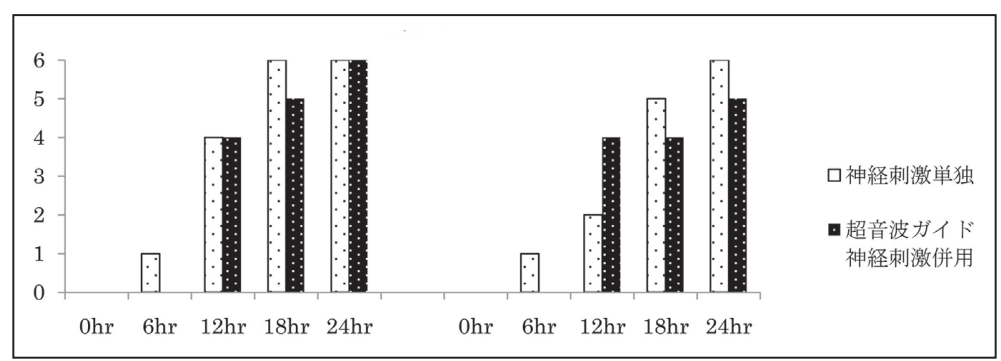

図8 感覚の回復

\section{$<$ 方法 $>$}

神経ブロックは全身麻酔導入前に軽度鎮静下で行 つた。それぞれのブロックは $0.25 \%$ ロピバカイン $30 \mathrm{~m} l$ を単回注入した。術後はフェンタニル持続静 脈内投与を行った。ブロックに要した時間，合併症 の有無, 術後 $0 ， 6 ， 12 ， 18 ， 24$ 時間後の安静時お よび体動時VASスコア, 感覚遮断および運動遮断 回復までの時間を両群間で比較検討した。

<結果 >

患者背景，使用した鎮静剂，麻薬性鎮痛剂の量， ブロックに要した時間は両群間で有意差を認めなか つた(表 1 , 表 2 , 図 3$)$ 。神経刺激単独群で 1 例, 傍 仙骨ブロック施行時に血液の逆流を認めた。術中循 環動態(心拍数, 平均血圧), 安静時VASスコア, 体動時VAS スコアは両群間で有意差を認めなかっ た(図4〜図7)。感覚遮断は両群とも, 手術終了後 12 時間後で回復し，両群間に有意差を認めなかっ た(図8)。坐骨領域の運動遮断は両群とも, 手術終 了後 12 時間から 18 時間で回復し, 両群間に有意差
を認めなかった(図 9, 図 10)。大腿神経の運動遮断 に関しては，創部の安静を必要としたため評価不可 能であった。

<考察 $>$

腰神経叢ブロック，傍仙骨ブロックともに神経刺 激単独法により施行されてきたために手技の習得が 難しく，ブロック効果が一定して得られなかった。

近年多くの未梢神経ブロックが超音波ガイド下で 施行されるようになったにもかかわらず，神経が深 部にあるブロックは標的となる神経の超音波画像描 出が難しいため超音波ガイド下で施行されてこなか った。腰神経叢は腎臓，腎動静脈，腹部大動脈，下 大静脈などが近傍に存在し ${ }^{3)}$, 後腹膜血腫が報告さ れており 1例は死亡している ${ }^{7)}$. 。傍仙骨ブロック も骨盤内臓器や血管が近接し，その誤穿刺による合 併症の危険性がある ${ }^{6}$ ．超音波ガイド下でのブロッ クはこれらの合併症を減少させる可能性が示唆され ている ${ }^{9)}$ ，われわれは今回，超音波解剖画像をラン ドマークとした超音波ランドマーク法による深部の 


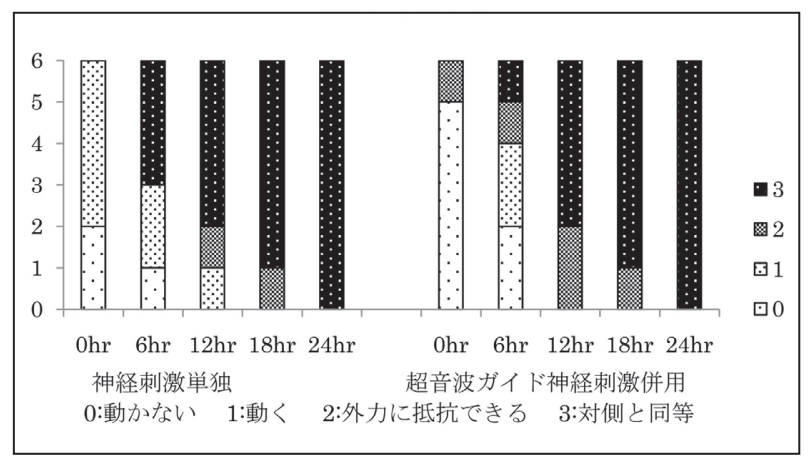

図 9 運動の回復(脛骨神経領域)

末梢神経ブロックを施行した。超音波ランドマーク 法は標的となる神経を超音波画像で描出できなくと も, 神経ブロックの指標となる骨組織や筋肉を超音 波画像で描出し，これらの組織の超音波画像をラン ドマークとした。超音波ランドマーク法は体表ラン ドマーク法に比べて，ブロック針を神経近傍まで容 易に進めることができ，安全に成功率の高い神経ブ ロックが可能となる。超音波ガイド・神経刺激併用 法とは, 超音波ランドマークを標識に神経刺激ガイ ド法を併用してブロック針を進め神経を確認する方 法である。

次にわれわれは TKAの術中術後鎮痛として神 経刺激単独法と超音波ガイド・神経刺激併用法によ る腰神経叢ブロックと傍脊椎ブロックを比較検討し た結果に両群間に差がないという結果を示した。安 静時 VASスコアにおいて神経刺激単独法が低いと いう傾向がみられたが，これは施行者が本研究開始 時点で神経刺激単独法では40例ほどの経験を積ん でおり，超音波ガイド・神経刺激併用法は経験がな かったことが一つの要因と考えられる。症例を重ね れば，この差はなくなると考える。また神経刺激単 独群で 1 例, 動脈誤穿刺を示唆する血液逆流(動脈 誤穿刺を示唆する) を認めた。血液逆流テストが陰 性であっても薬液血管内注入を防ぎえないことが知 られている。また，超音波ガイド下神経ブロックで は注入した薬液が血管内注入されると, 薬液の神経 近傍の広がりがみられないことから血管内注入を早

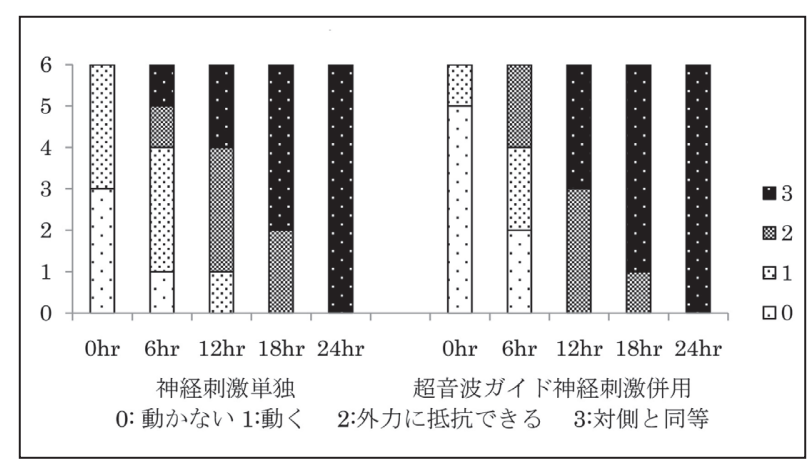

図 10 運動の回復(腓骨神経領域)

い段階で検出できるとの報告がある ${ }^{10), 11}$.これらは, 超音波画像による薬液血管内注入検出は血液逆流テ ストに比べて感受性がよいことを示唆している。さ らに，超音波ガイド下ブロックは針の穿刺回数の減 少，手技に要する時間の短縮，合併症の発生率の低 下，手技習得学習曲線の向上が期待される.

\section{おわりに}

神経の超音波画像描出が難しいため超音波ガイド 下で施行されてこなかった深部ブロックを，神経ブ ロックの指標となる骨組織や筋肉を超音波画像で描 出し, これらの組織の超音波画像をランドマークと し，神経刺激と併用して施行した。超音波ガイド・ 神経刺激併用法は神経刺激単独法と同様な神経遮断 効果が深部末梢神経ブロックで得られことを示し た。また，超音波ガイド・神経刺激併用法は症例を 重ねることにより手技の向上と合併症減少の可能性 があり, 将来, 深部の末梢神経ブロックの標準的神 経ブロック法となると推察される。

\section{参考文献}

1) Wang H, Boctor B, Verner J : The effect of single-injection femoral nerve block on rehabilitation and length of hospital stay after total knee replacement. Reg Anesth Pain Med 27 : 139-144, 2002

2) Horlocker TT, Wedel DJ, Benzon H, et al. : Regional anesthesia in the anticoagulated patient: defining the risks (the second ASRA Consensus Conference on 
Neuraxial Anesthesia and Anticoagulation). Reg Anesth Pain Med 28 : 172-197, 2003

3) Chayen D, Nathan H, Chayen M : The psoas compartment block. Anesthesiology 45 : 95-99, 1976

4) Capdevila X, Macaire P, Dadure C, et al. : Continuous psoas compartment block for postoperative analgesia after total hip arthroplasty : new landmarks, technical guidelines, and clinical evaluation. Anesth Analg 94 : 1606-1613, 2002

5) Morris GF, Lang SA, Dust WN, et al. : The parasacral sciatic nerve block. Reg Anesth 22 : 223-228, 1997

6) O'Connor M, Coleman M, Wallis F, et al. : An anatomical study of the parasacral block using magnetic resonance imaging of healthy volunteers. Anesth Analg $108:$ 1708-1712, 2009

7) Aveline C, Bonnet F : Delayed retroperitoneal haematoma after failed lumbar plexus block. Br J Anaesth
$93: 589-591,2004$

8) Montoya JP, Pokala N, Melde SL : Retroperitoneal hematoma and enoxaparin. Ann Intern Med 131 : 796797, 1999

9) Walker KJ, McGrattan K, Aas-Eng K, et al. : Ultrasound guidance for peripheral nerve blockade. Cochrane Database Syst Rev(4) : CD006459, 2009

10) Martínez Navas A, DE LA Tabla González RO : Ultrasound-guided technique allowed early detection of intravascular injection during an infraclavicular brachial plexus block. Acta Anaesthesiol Scand 53 : 968-970, 2009

11) VadeBoncouer TR, Weinberg GL, Oswald S, et al. : Early detection of intravascular injection during ultrasound-guided supraclavicular brachial plexus block. Reg Anesth Pain Med 33 : 278-279, 2008

\title{
Comparing Dual Guidance with Ultrasound and Nerve Stimulator in Combination versus Nerve Stimulator Alone for Lumbar Plexus Block and Parasacral Nerve Block in Patients Undergoing Total Knee Arthroplasty
}

\author{
Misako HARATO, Hiroshi ITO, Manabu AKASHI, \\ Toru KOMATSU, Yoshihiro FUJIWARA \\ Department of Anesthesiology, Aichi Medical University
}

Lumbar plexus block and parasacral block provide high quality analgesia in patients undergoing total knee arthroplasy (TKA). Both blocks used to be performed using nerve stimulator and land mark guidance(Landmark Group). Identification of the sonoanatomical structures of the parasacral nerve or lumbar plexus located deep inside the body is very difficult. However, we could identify the structures of the bone and muscle around parasacral nerve or lumbar plexus and the tip of the needle by ultrasound guidance. The quality of the nerve block could be improved by using those sonoanatomical images as landmark and nerve stimulation in combination(Dual guided Group). In this study, efficiency of the block, and block execution time were similar between the Landmark Group and Dual guided Group. One patient in Landmark Group showed blood aspiration during needle puncture when parasacral nerve block was performed, suggesting an accidental puncture of the inferior gluteal artery. Dual guided nerve block is theoretically superior as compared to the nerve block guided by the nerve stimulator alone and may prevent complications.

Key Words : Lumbar plexus block, Parasacral block, Dual guided, TKA, Postoperative analgesia 